\title{
STUDI TENTANG JENIS KRUSTASEA YANG HIDUP DI KARANG BATU DAN PERANANNYA DALAM EKOSISTEM TERUMBU KARANG
}

\author{
Oleh \\ Rianta Pratiwi 1)
}

\begin{abstract}
STUDIES ON CRUSTACEANS SPECIES LIVING IN THE CORAL REEF AND THEIR ROLE IN ECOSYSTEM. Crustaceans are one of the most specis invertebrates in coral reefs, comprising approximately $20 \%$ of all invertebrate species. This taxa often found clearly living in coral communities. The order Decapoda is the most common crustaceans observed the coral reefs due to their relatively large size and having bright colours. In addition, decapods contribute in the environmental balance and having important roles in coral reef ecosystem such as defending live coral from predators and helping growth of corals.
\end{abstract}

\section{PENDAHULUAN}

Krustasea merupakan kelompok biota laut yang banyak dijumpai di perairan dan memiliki nilai ekonomis, serta peran yang cukup penting di ekosistem terumbu karang (Abele \& Patton, 1976) dengan kontribusi sekitar $20 \%$ dari semua spesies invertebrata (Plaisance et al., 2011; Stella et al., 2011). Krustasea hampir secara eksklusif diwakili oleh ordo Decapoda, karena ordo tersebut merupakan kelompok yang sering diamati, karena ukurannya yang relatif besar dan memiliki warna-warna yang cerah (Kramer et al., 2014).

Salah satu peran penting krustasea (Decapoda) adalah menjaga terumbu karang dari predator di perairan, dengan cara selalu menjaga serangan dari biota-biota yang akan menempati karang batu, kepiting akan mengusir moluska atau bintang mengular (Echinoid) yang melekat di karang. Biasanya moluska dan bintang mengular hanya akan berada dan atau bersembunyi di bawah batu karang (Pratchett, 2001). Disamping Krustasea merupakan fauna yang habitat dan penyebarannya terdapat di air tawar, payau dan laut, makajenis-jenisnya sangat beragam dan dapat hidup di berbagai kolom di setiap perairan. Contohnya adalah sebagian krustasea yang dijumpai hidup di perairan laut terutama di dalam ekosistem terumbu karang. Beberapa jenis krustasea yang umum hidup dalam ekosistem tersebut, antara lain adalah dari kelompok Kepiting batu (Xanthidae, Tetraliidae, Trapeziidae), Lobster (Udang karang), Udang pistol (Alpheidae), dan Kelomang (Hermit crab) (Pratiwi, 1993, Pratiwi, 1990). Dari sekian banyak jenis

\footnotetext{
${ }^{1)}$ Peneliti Biodiversitas dan Konservasi Ekosistem Laut, Pusat Penelitian Oseanografi-LIPI, Jakarta.
} 
biota yang termasuk dalam kelompok krustasea, namun hanya ada beberapa saja yang banyak dikenal orang karena biasa dimakan, dan berukuran agak besar. Jenis yang tubuhnya berukuran kurang dari $6 \mathrm{~cm}$ tidak lazim dimakan karena terlalu kecil dan hampir tidak mempunyai daging (Pratiwi, 1993). Beberapa jenis krustasea tersebut di atas ada juga yang dapat menimbulkan keracunan apabila dikonsumsi, namun dalam tulisan ini hal tersebut tidak dibahas.

Terumbu karang merupakan rumah atau tempat berlindung berbagai biota laut diantaranya: ikan, moluska, ekhinodermata, rumput laut dan krustasea yang hidup berasosiasi dengan karang batu, sehingga memiliki peran yang sangat penting dalam ekosistem laut. Mengingat peranan krustasea yang penting bagi suatu perairan dan ekosistem, maka perlu dilakukan penelitian untuk memberikan informasi pengetahuan tentang kehidupan krustasea. Tujuan penulisan ini adalah untuk memberikan informasi mengenai peranan kepiting di ekosistem terumbu karang sebagai biota yang membantu pertumbuhan karang, serta tempat penyedia makanan alami bagi crustacea dan hewan lain yang sangat penting bagi kelangsungan kehidupan krustasea di perairan.

\section{JENIS-JENIS KRUSTASEA YANG HIDUP DI KARANG BATU}

\section{Kepiting Suku Xanthidae, Tetraliidae dan Trapeziidae}

Kelompok kepiting dari Suku Xanthidae, Tetraliidae dan Trapeziidae terdiri dari banyak jenis dan biasanya dijumpai di celah-celah karang batu yang bercabang. Kelompok kepiting ini hidup bersimbiosis dengan karang batu dan saling menguntungkan satu dengan lainnya. Kelompok ini dikenal pula dengan sebutan kepiting batu, terutama kelompok suku Xanthidae, karena mereka dapat berkamuflase mirip dengan karang batu yang merupakan habitat hidupnya. Mereka hidup dalam celah-celah karang batu dengan cara mencengkram karang batu menggunakan capit-capitnya yang kuat (Gambar 1).

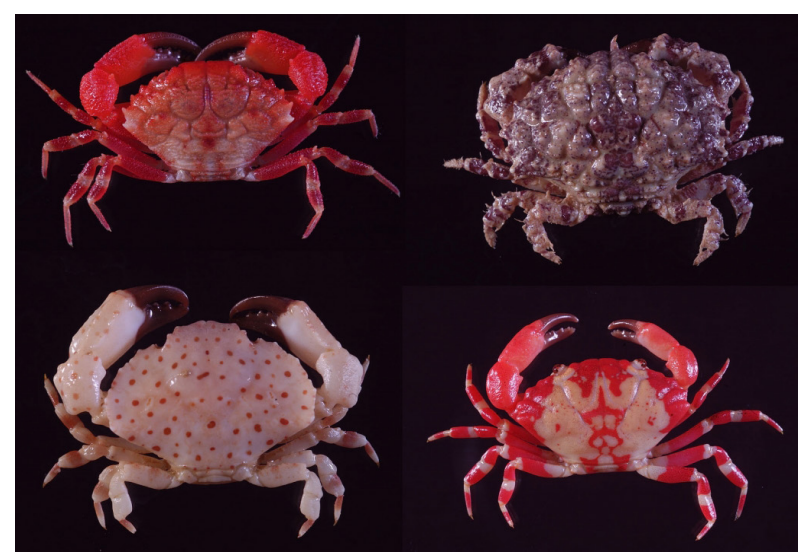

Gambar 1. Jenis-jenis kepiting yang termasuk dalam suku Xanthidae (Foto : Koleksi Pribadi). 
Kelompok kepiting lainnya adalah dari Suku Tetraliidae dan Trapeziidae (Gambar2) banyak menghuni karang batu, khususnya pada karang dari Marga Pocillopora dan Acropora. Trapezia adalah Marga kepiting dari Suku Trapziidae. Suku Trapeziinae yang mempunyai bentuk tubuh sangat khusus. Bentuk karapasnya sangat istimewa, yakni memipih (depressed) hampir menyerupai trapesium (quadrilateral) dengan permukaan dorsal yang licin, mengkilap dan berwarna terang (Sakai,
1976 a, b), Galil \& Lewinsohn, 1985). Dari bentuk tubuh yang hampir seperti trapesium inilah secara tidak langsung terbentuk nama marga ini. Jenis kepiting ini umumnya memiliki ukuran lebar karapas lebih besar daripada panjangnya (Gambar 2). Perbedaan corak, warna serta perbedaan morfologi duri anterolateral dan rostrumnya umum digunakan sebagai kriteria oleh beberapa peneliti untuk membedakan jenis, anak jenis, dan varietasnya (Patton, 1976; Castro, 1976).

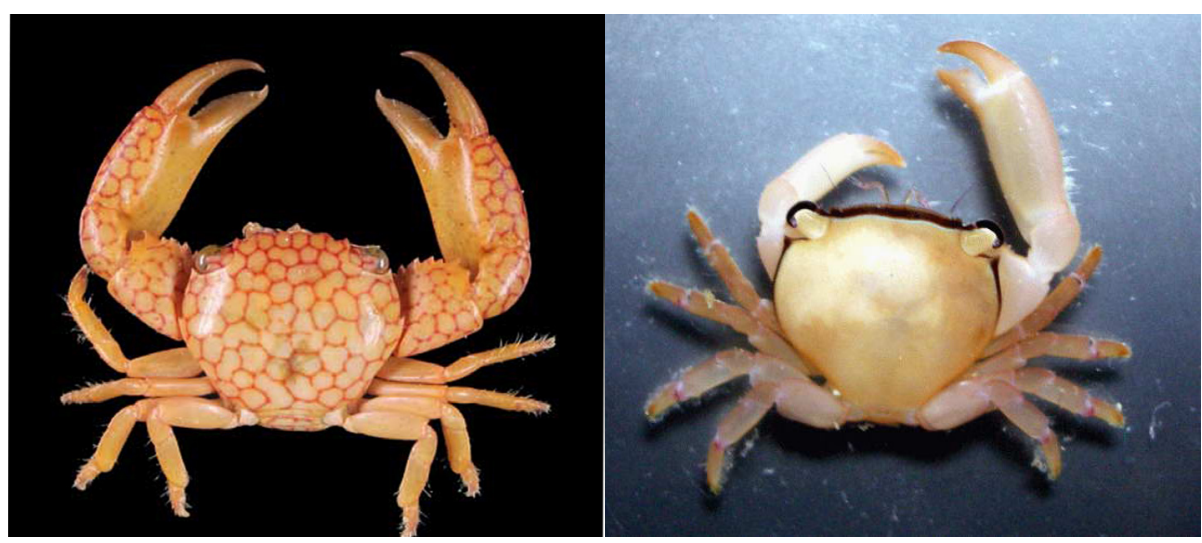

A

$\mathrm{B}$

Gambar 2. A. Kepiting marga Trapezia; B. Kepiting marga Tetralia (Foto : Koleksi Pribadi).

\section{Udang Karang Suku Palinuridae}

Udang Karang atau Udang Barong, yang memiliki nama ilmiah Panulirus dan termasuk dalam Suku Palinuridae. Di Indonesia udang karang hanya ditemukan enam jenis yang tersebar dari perairan Indonesia Barat hingga Indonesia Timur dengan tipe habitat yang berbeda beda. Keenam jenis udang karang tersebut adalah: 1. udang kendal, udang rejuna, udang barong, lobster hijau atau lobster bambu (Panulirus versicolor); 2. udang jaka atau udang batu (Panulirus penicillatus); 3. udang bunga atau raja udang (Panulirus longipes); 4. udang ketangan, udang cemara atau lobster mutiara (Panulirus ornatus); 5. udang jarak (Panulirus polyphagus); dan 6. udang pantung, udang bireng atau lobster hijau pasir (Panulirus homarus) (Gambar 3) (Moosa, 1984a; Moosa \& Aswandy, 1984b; Romimohtarto \& Juwana, 1999; Setyono, 2006; Pratiwi, 2013). 
Udang karang biasanya hidup di daerah-daerah karang, bersembunyi di dalam lubang atau dibalik batu-batu karang, yang airnya dangkal ataupun laut dengan kedalaman lebih dari 400 meter di daerah tropis, sub tropis ataupun semi-tropis (Romimohtarto \& Juwana 1999). Udang karang sangat melimpah dan merupakan jenis yang komersial di sepanjang pantai utara dan selatan Amerika, Afrika, Mediteranean, India, Australia, Selandia Baru dan peraian Indo Pasifik (termasuk perairan Indonesia) (Romimohtarto \& Juwana, 1999; Pratiwi, 2013). Meskipun memiliki morfologi yang sama, tetapi habitat mereka berbedabeda tergantung dari jenisnya.

A

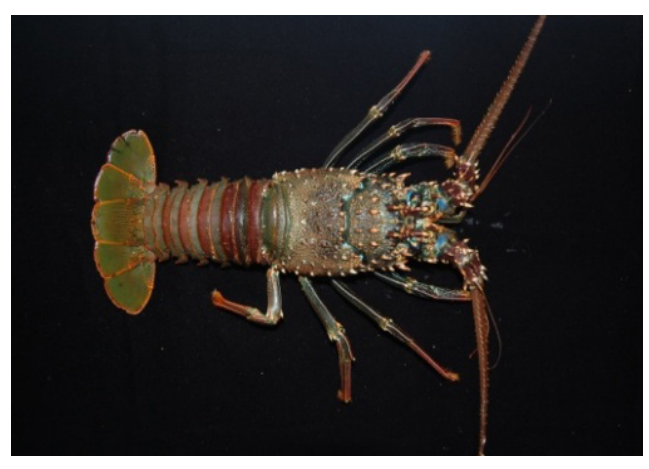

C

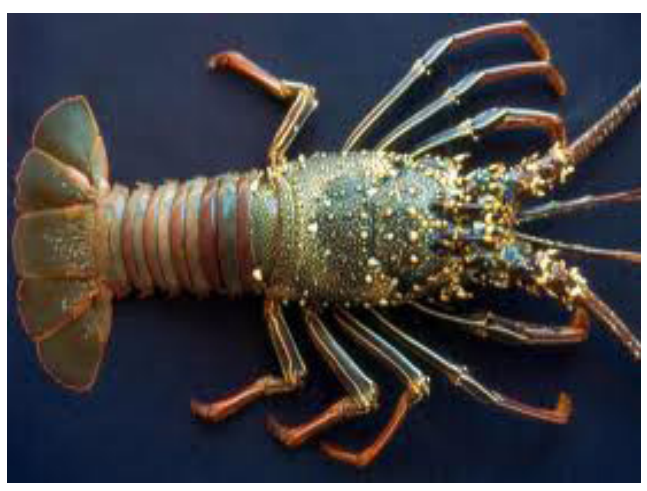

Keragaman jenis udang karang lebih besar di daerah perairan tropis dan sub tropis, tetapi kepadatannya relatif rendah. Sebaliknya, keragamanan jenis akan berkurang di daerah perairan hangat (temperate), tetapi kepadatannya seringkali tinggi. Di lingkungan yang lebih hangat, proses pergantian kulit (moulting) terjadi lebih sering dan tingkat pertumbuhan menjadi lebih cepat, meskipun ukuran dewasa maksimalnya mungkin berkurang (Morgan, 1977). Jenis-jenis udang ini sering beruaya menurut pola tertentu, yakni dalam kelompok-kelompok yang membentuk barisan (Romimohtarto \& Juwana, 1999).

B

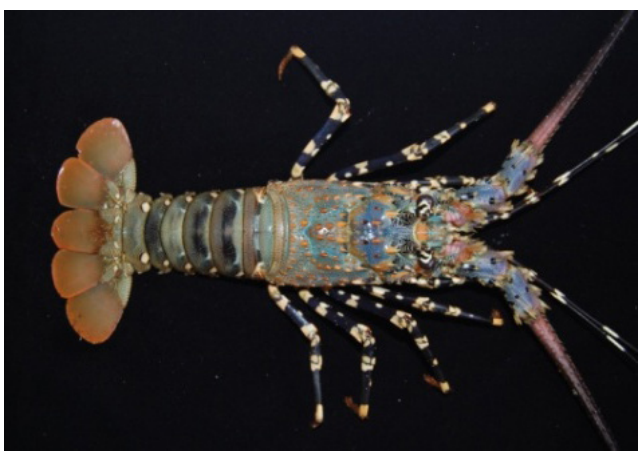

D

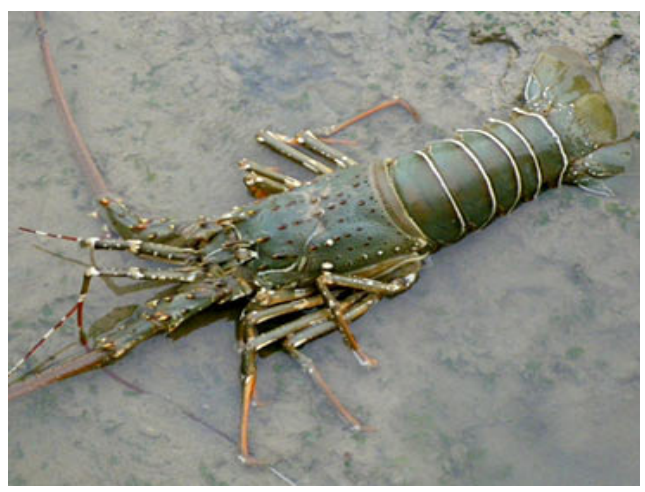


$\mathbf{E}$

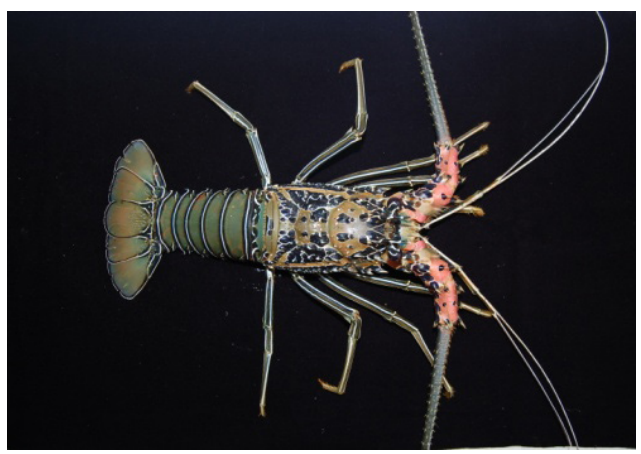

F

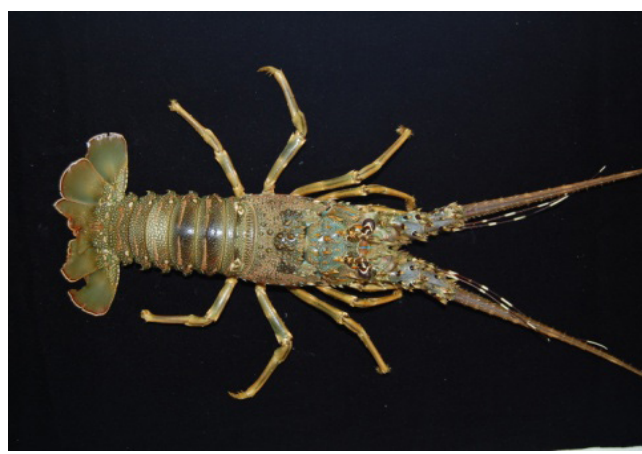

Gambar 3. Jenis-jenis lobster yang ada di perairan Indonesia. a. Panulirus versicolor (lobster hijau/bambu); b. Panulirus homarus (lobster hijau pasir); c. Panulirus longipes (lobster bunga); d. Panulirus ornatus (lobster mutiara); e. Panulirus penicillatus; f. Panulirus polyphagus (Foto: Koleksi pribadi Pratiwi, 2013).

\section{Udang Pistol Suku Alpheidae}

Udang pistol Marga Alpheus merupakan anggota dari Suku Alpheidae atau lebih dikenal dengan sebutan udang pistol, karena capit besarnya dapat menimbulkan suara yang keras seperti suara pistol pada saat predator menyerang atau merasa ada bahaya disekitarnya. Manfaat ekonomi dari udang ini bagi manusia memang tidak ada, tubuhnya berukuran relatif kecil (hanya sekitar $3 \mathrm{~mm}-12 \mathrm{~cm}$ ), sehingga tidak dapat dimakan. Udang ini biasanya mempunyai bentuk rostrum yang pendek dan tubuh yang halus. Karapas selalu dilengkapi oleh cardiac notch (lekukan) di bagian ujung posterior, dan bagian tepi pterygostomial biasanya membulat (Gambar 4).

Antenulla biasanya pendek dengan stylocerite yang kadang-kadang sudah tereduksi. Basicerite pada beberapa jenis Alpheus ada yang dilengkapi oleh gigi-gigi ventral dan ada yang tidak, sehingga bentuknya bulat, tidak mempunyai scaphocerite atau kadangkadang ada, tetapi mengalami reduksi. Carphocerite biasanya dimulai dari atau diantara bagian ujung dari scaphocerite (Banner, 1953; Banner \& Banner, 1982; 1985; Pratiwi, 1993).

Sapit (chela) pasangan kaki pertama biasanya berbentuk asimetris. Sapit besar (major chela), mempunyai bentuk yang bervariasi pada masingmasing jenis, mulai dari yang halus subsilindris sampai dengan yang kokoh dan pipih, dengan "palm" yang dalam dan kuat. Sapit gerak (movable finger) biasanya dilengkapi dengan gigi-gigi molar. Sapit kecil (minor chela), mempunyai bentuk yang sederhana, kadang-kadang menunjukkan dimorphisme kelamin yang ditandai dengan sapit gerak yang ditumbuhi oleh bulu-bulu halus (setae) dan pada yang jantn berbentuk "balaeniceps" (Gambar 4) (Banner \& Banner, 1953; 1966; 1993). 


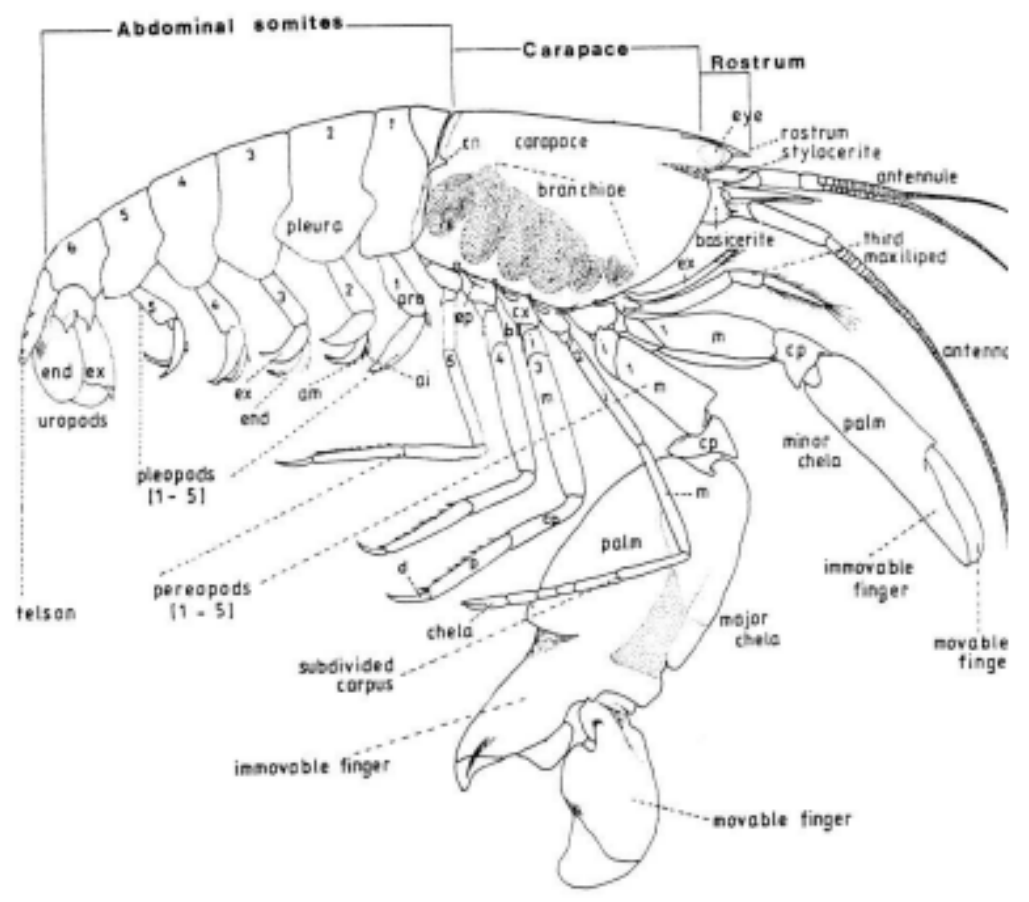

Gambar 4. Morfologi udang pistol (Alpheus shrimps) (Kim \& Abele, 1988).

Carpus dari pasangan kaki kedua pereiopod, selalu dilengkapi dengan lima buah segmen yang ukurannya bervariasi. Daktilus biasanya berbentuk simpel (sederhana) (Banner \& Banner, 1982).

\section{Kelomang (hermit crabs)}

Kelomang atau kumang sudah lama dikenal terutama oleh anak-anak sebagai teman bermain. Hewan ini mempunyai keunikan tersendiri, yakni bersembunyi di dalam cangkang moluska yang selalu dibawa kemana saja. Biasanya anak-anak dengan mudah memperoleh hewan ini, baik mencari sendiri di pantai, batu-batu karang, atau di bawah tumpukkan sampah di pinggir pantai (Pratiwi, 1990). Kelomang memang bukan hewan yang termasuk hidup atau bersimbiose pada terumbu karang, tetapi hidup di bawah karang batu hanya untuk sementara waktu. Beberapa jenis kelomang dari suku Coenobitidae dan Paguridae biasanya akan memanfaatkan karang batu di saat hewan-hewan tersebut belum mendapatkan cangkang moluska sebagai tempat pelindung tubuh. Caranya adalah kelomang-kelomang tersebut membenamkan diri dalam substrat di bawah karang batu, sambil mengamati kondisi sekitar apabila terdapat cangkang moluska atau moluska yang dapat diambil cangkangnya (Mc Laughlin; 1979; Hazlett;1966; 1969).

Kelomang mempunyai struktur tubuh yang memanjang, asimetris, silindris dan pipih. Ciri lain dari tubuh yang asimetris ini adalah pleopod hanya terletak disebelah kiri abdomen, 
meskipun beberapa kelomang dari Marga Coenobita primitif mempunyai sepasang pleopod (Mc Laughlin, 1979). Kriteria inilah yang dipakai untuk memisahkan kelomang dari kepiting-kepiting lain secara taksonomi.

Struktur tubuh kelomang sudah mengalami modifikasi dan evolusi, yang dicirikan oleh karapas yang menyempit dan tidak mengeras sebagai pelindung tubuhnya yang lunak, disamping bentuk abdomen yang memanjang (Gambar 5) (Mc Laughlin, 1979). Selain mencari makan, istirahat, kopulasi dan berkembang biak, aktivitas utama yang menentukan hidupnya ialah berburu cangkang. Kelomang akan selalu berganti-ganti cangkang sebagai tempat tinggal dan berlindung. Cangkang yang biasa dimanfaatkan dan biasanya dari moluska Kelas Gastropoda. Ukuran cangkang yang dipilih disesuaikan dengan ukuran tubuhnya. Kelomang muda yang berukuran kecil akan memilih cangkang siput kecil, misalnya siput dari Marga Littorina, sedangkan kelomang dewasa yang berukuran besar cenderung memilih cangkang dari siput Kelas gastropoda yang lebih besar atau disesuaikan dengan ukuran tubuh kelomang (Monkman, 1997). Berbeda dengan ketam kelapa (Birgus latro) yang juga termasuk hermit crabs (Coenobitidae), jenis ketam ini termasuk hewan yang banyak menghabiskan waktunya di darat dan hanya menggunakan cangkang gastropoda semasa tahap post larva, glaucothoe dan ketam muda saja. Pada tahapan-tahapan itu cangkang tersebut hanya digunakan untuk bermigrasi dari laut ke darat saja. Perilaku ini dimaksud untuk melindungi diri dari kekeringan dan keadaan darurat lainnya selama tahap yang rawan dalam kehidupannya. Apabila proses adaptasi telah tercapai, maka perilaku membawa cangkang tersebut tidak lagi diteruskan hingga dewasa (Reese, 1968; Pratiwi, 1990).

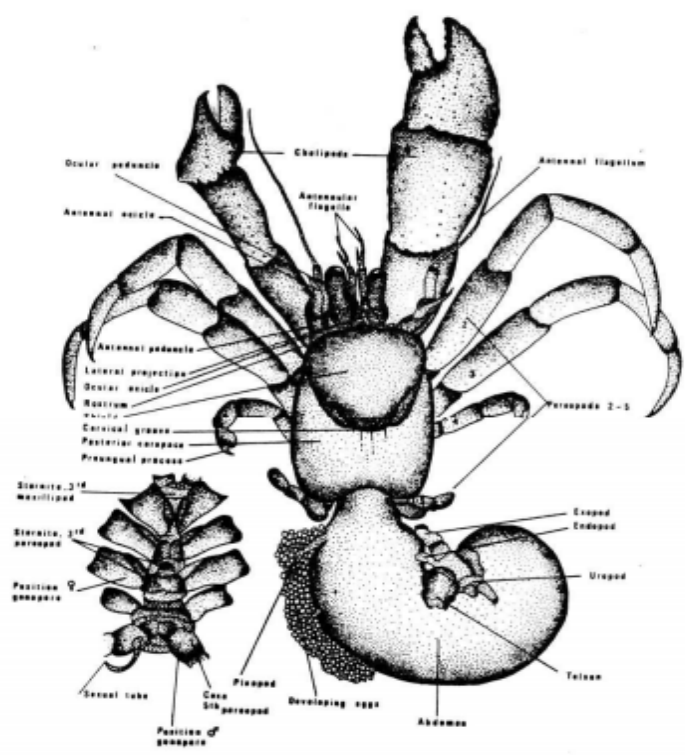

Gambar 5. Morfologi kelomang (Decapoda, Aniomura, Paguroidea) (Mc Laughlin, 1979) 


\section{PERANAN KRUSTASEA DALAM EKOSISTEM TERUMBU KARANG}

Walaupun kepiting dari Suku Xanthidae, Tetraliidae dan Trapeziidae tidak memiliki nilai ekonomi penting, namun dari segi biologis kepiting tersebut dapat membantu pertumbuhan dan kelestarian karang batu. Di alam, kepiting Trapezia dan Tetralia ditemukan hidup bersimbiosis pada karang-karang batu yang hidup. Marga kepiting tersebut menurut Patton (1976), Abele \& Patton (1976), Kramer et al. (2013) memiliki cara tersendiri dalam menempati habitatnya, dan dapat beradaptasi dengan baik pada lingkungannya. Mereka dapat masuk ke celah-celah cabang karang, kemudian melekat dengan kuat pada bagian karang yang ditempatinya. Kekuatan pelekatan terutama disebabkan oleh adanya kaki pejalan yang mempunyai daktil besar dan tumpul. Pada daktil terdapat duri-duri kecil yang runcing dan tajam berguna untuk membantu pergerakan mengelilingi cabang-cabang karang secara cepat dan tangkas. Aktivitas kehidupan kedua kepiting yang demikian menyebabkan pertumbuhan polip karang akan tumbuh dengan cepat. Keuntungan yang didapat oleh kepiting antara lain: mendapatkan perlindungan dan makanan yang melekat di bagian polip-polip karang, sedangkan polip karang akan bertumbuh dengan cepat karena bantuan capit dan kakikaki kepiting yang mengais-ngais, mengkorek-korek atau berjalan disekitar polip karang.

Sedangkan kehidupan udang karang di alam baik yang juvenil dan maupun dewasa, sebagian besar dijumpai di daerah terumbu karang perairan dangkal. Belum diketahui persis peranannya dalam ekosistem terumbu karang, tetapi sebagai kelompok crustacea lobster tergolong memiliki nilai ekonomis penting dan sangat dicari oleh nelayan-nelayan hampir di seluruh perairan Indonesia (Setyono, 2006) .

Kelompok udang pistol (Alpheus spp.) Suku Alpheidae juga tidak memiliki nilai ekonomis penting, tetapi dalam kehidupannya di alam, udang-udang tersebut mempunyai peranan yang penting dalam kehidupan bersimbiosis dengan ikan Cryptocentrus spp. (Gobiidae). Mereka menjalin kehidupan bersama di dalam lubang di dasar perairan yang dangkal, sekitar 3-5 meter (Karplus et al., 1972). Sepanjang kehidupan udang Alpheus selalu ditemani oleh ikan gobi dan kehidupn tersebut berjalan sangat erat, saling menjaga dan saling memberi. Kehidupan bersama tersebut dimulai dengan penggalian lubang oleh udang Alpheus. Lubang biasanya tidak terlalu dalam dan berfungsi sebagai tempat tinggal untuk dihuni bersama. Biasanya ikan gobi hanya tinggal sementara saja di siang hari, sedangkan pada malam hari akan digunakan sebagai tempat beristirahat (Karplus et al., 1972). Saat akan keluar dari lubang, ikan gobi akan "menuntun atau menggandeng" udang Alpheus. Ikan gobi tersebut akan berada diposisi depan dan udang akan menempelkan antenanya pada ekor ikan. Mereka akan selalu "bergandengan" hingga di luar lubang. Demikian pula bila mereka akan kembali memasuki lubang, udang akan berjalan mundur 
dengan posisi tetap dibelakang dan “ bergandengan”. Hal ini selalu dilakukan karena udang tidak dapat melihat dalam gelap (lubang) yang mana dalam hal ini lubang galian selalu memiliki kondisi yang gelap (Karplus, 1987; Karplus et al., 1972; Karplus et al., 1974). Selain mencari makan, aktivitas lain dalam lubang adalah membersihkan tubuh ikan (cleaning). Udang akan membersihkan tubuh ikan dari sisa-sisa makanan atau kotoran yang menempel di tubuhnya. Bagian tubuh yang dibersihkan biasanya hanya bagian kepala (mata dan mulut) serta ekor. Tingkah laku ini berlangsung sangat akrab dan dinamakan "Mutual Beneficial Activity” (Karplus et al., 1974).

\section{PENUTUP}

Kehidupan di alam dari biota dan organisme dengan lingkungan hidupnya di laut khususnya crustacea, memang sangat luar biasa dan sudah diatur oleh Sang Pencipta Alam Semesta ini. Masing-masing jenis crustacea baik kepiting maupun udang dan kelomang sudah mempunyai peranan masingmasing dalam kehidupannya, saling membantu dan saling menguntungkan.

Lingkungan hidup, terkhusus ekosistem terumbu karang menjadi sangat terjaga dengan kehadiran dari hewan-hewan kelompok krustasea tersebut. Terumbu karang sebagai rumah atau tempat berlindung berbagai biota laut mempunyai fungsi yang sangat penting bagi hewanhewan asosiasi tersebut. Inilah kehidupan yang saling menguntungkan dalam ekosistem terumbu karang.

\section{DAFTAR PUSTAKA}

Abele, L.G. and W.K. Patton, 1976. The size of coral heads and the community biology of associated decapod crustaceans. J. Biogeogr 3: 35-47.

Banner, A.H. 1953. The Crangonidae or snapping shrimps of Hawaii. Pac. Sci. 7 (1): 1-147.

Banner, A.H. and D.M. Banner, 1966. The Alpheid shrimp of Thailand. The Alpheid shrimp of the Gulf of Thailand and adjacent waters. The Siam Society Monograph series 3 (6): $168 \mathrm{pp}$.

Banner, D.M. and A.H. Banner, 1982. The Alpheid shrimps of Australia, Part III: The remmaining Alpheids, principally the Genus Ogrydidae. Rec. Australian Mus, 34 (1): 1-357.

Banner, D.M. and A.H. Banner, 1985. The Alpheids shrimps of Indonesia. Based Upon.

J.G. de Man's. 1911.“ The Decapoda of the Siboga Expedition, Part II: Family Alpheidae" Mar. Res. Indonesia, 25: $79 \mathrm{pp}$.

Banner, A.H. 1993. The Crangonidae, or snapping shrimp, of Hawaii. Pac. Sci. 7 (1): 1- 147.

Castro, P., 1976. Brachyuran crabs symbiotic with Scleractinian corals: a review of their biology. Micronesica, J. Coll. Guam, 12: 99-110. 
Galil, B., and C.H. Lewinsohn. 1985. On the taxonomic status of Trapezia areolata DANA and Trapezia septata DANA (Decapoda, Brachyura). Crustaceana 48 (2): 209-217.

Hazlett, B.A. 1966. The behaviour of some deep-water hermit crabs (Decapoda: Paguridae) from the strait of Florida. Bull Mar. Sci. 16 (1): 76-91.

Hazlett, B.A. 1969. Stone fighting in the crab Cancellus spongicola (Decapoda: Anomura, Diogenidae). Crustaceana, 16 (2): 219-220.

Kim, W. and L.G. Abele, 1988. The snpping shrimp genus Alpheus from the eastern Pacific (Decapoda, Caridea, Alpheidae). Smithsonian Contr. Zool, 454: $119 \mathrm{p}$.

Karplus, I. 1987. The association between gobiid fishes and burrowing alpheid shrimps. Oceanogr. Mar. Biol. Annu. Rev., 25: 507-562.

Karplus, I., R. Szelp and M. Tsurnamal. 1972. Associative behavior of the fish Cryptocentrus cryptocentrus (Gobiidae) and pistol shrimp Alpheus djiboutensis (Alpheidae) in artificial burrows. Mar. Biol. 15: 95-104.

Karplus, I., R. Szelp and M. Tsurnamal. 1974. The burrows alpheid shrimp associated with gobiid fish in the Northern Red Sea. Mar. Biol. 24: 259-268.
Kramer, M.J., D.R. Bellwood and O. Bellwood. 2014a. The trophic importance of algal turft for coral reef fishes: the crustacean link. Coral Reefs, 32: 575-583.

Kramer, M.J., D.R. Bellwood and O. Bellwood. 2014b. Benthic crustacea on coral reefs: a aquantitative survey. Mar Ecol Prog Ser, 511: 105-116.

Mc Laughlin, P.A. 1979. Comparative morphology of recent Crustacea. W.H. FREEMAN and Company, San Francisco, 177 pp.

Monkman, N. 1997. Crustaceans: A selection from Queensland to the Great Barrier Reef. In: Wild, wild world of animals life in the coral reef. Corals, Anemones, Crustaceans, Sea Stars, Sponges, Mollusks, Sea Urchins. Based on the television series wild, wild world of animals. ELEANOR GRAVES (ed), America. 48-63.

Morgan, G.R. 1977. Adult ecology and population dynamics of the Palinuridae a review. Circ. CSIRO, Div. Fish. Oceanogr. (Aust): 7: 245-258.

Moosa, M.K. 1984a. Udang karang (Panulirus spp.) dari perairan Indonesia. Lembaga Oseanologi Nasional, LIPI. Jakarta: 40 hal.

Moosa, M.K., and I. Aswandy. 1984b. Udang karang (Panulirus spp.) dari perairan Indonesia. Proyek Studi Potensi Sumber 
Daya Hayati Ikan. Lembaga Oseanologi Nasional, Lembaga Ilmu Pengetahuan Indonesia, Jakarta, 40 hal.

Patton, W.K. 1976. Decapod crustacea commensal with Queensland branching corals. Crustaceana 10: 284-295.

Plaisance, L. M.J. Caley, R.E. Brainatd and N. Knowton. 2011. The diversity of coral reefs: What are we missing? PloS ONE 6:e25026.

Pratiwi, R. 1990. Keunikan tingkah laku kepiting pertapa (Hermit Crab). Oseana XV (3): 127-133.

Pratiwi, R. 1993. Beberapa catatan mengenai udang pistol. Oseana XVIII (2): 77-85.

Pratiwi, R. 2013. Lobster Komersial. Oseana XXXVIII (2): 55-68.

Pratchett, M.S. 2001. Influence of coral symbionts on feeding preferences of crown of thorns starfish Acanthaster planci in the western Pacific. Mar.Ecol. Prog Ser 214: 111-119.

Prianto, E. 2007. Peran Kepiting sebagai Spesies Kunci (Keystone Spesies) pada Ekosistem Mangrove. Prosiding Forum Perairan Umum Indonesia IV. Balai Riset Perikanan Perairan Umum. Banyuasin.
Reese, E.S. 1968. Shell use: an adaptation for emigration from the sea by the Coconut Crab. Science, 161: 385-386.

Romimohtarto, K. dan S. Juwana, 1999. Biologi laut. Ilmu pengetahuan tentang biologi laut. Pusat Penelitian dan Pengembangan Oseanologi-LIPI, Jakarta, 527 hal.

Sakai, T. 1976a. Crabs of Japan and the adjacent seas. Kodansha Japan, 773 pp.

Sakai, T. 1976b. Crabs of Japan and the adjacent seas plates. Kodansha Japan, 251 pp.

Setyono, D.E.D 2006. Budidaya pembesaran udang karang (Panulirus spp.). Oseana, 31 (4): 39-48.

Stella, J.S., M.S. Pratchett, P.A. Hutching, and G.P. Jones, 2011. Coral associated invertebrates: diversity, ecological importance and vulnerability to disturbance. Oceanogr Mar Biol Annu Rev, 49: 43-104.

Warner, G.F. 1977. The biology of crabs. Elek Science, London: 197 pp. 